\title{
LEGAL CONSCIOUSNESS AS A FACTOR PROMOTING THE ACHIEVEMENT OF EDUCATIONAL OBJECTIVES AND THE REALIZATION OF THE RIGHT TO EDUCATION BY INDIVIDUALS AND COLLECTIVES
}

\section{A CONSCIÊNCIA JURÍDICA COMO FATOR DE PROMOÇÃO DA REALIZAÇÃO DOS OBJETIVOS EDUCACIONAIS E DA REALIZAÇÃO DO DIREITO À EDUCAÇÃO DE PESSOAS E COLETIVOS}

\section{LA CONCIENCIA JURÍDICA COMO FACTOR QUE PROMUEVE EL CUMPLIMIENTO DE LOS OBJETIVOS EDUCATIVOS Y LA REALIZACIÓN DEL DERECHO A LA EDUCACIÓN DE LAS PERSONAS Y COLECTIVOS}

\author{
Elena Anatolyevna Tereshchenko ${ }^{1 *}$ \\ Vladimir Viktorovich Kovalev ${ }^{2}$ \\ Maxim Sergeevich Trofimov ${ }^{3}$ \\ Dzambolat Arthurovich Zasseev ${ }^{4}$
}

\begin{abstract}
The article studies the legal consciousness of participants to educational activities in the process of achieving educational objectives and realizing their right to education. Obstacles that are typical of such a type of research conditioned by an insufficient theoretical basis for studying legal consciousness in general and as a category accompanying the realization of goals, capabilities and rights of participants to educational activities. In the Russian legal science, these obstacles are caused by the prevalence of ideological dogmas over objective scientific approaches (for example, the concept that state and law will wither away as unnecessary institutes alongside the formation of communism), which is emphasized by Russian scholars concerned with these issues. Over time, the above-mentioned difficulties have been overcome and today the issues associated with legal consciousness (in particular, individuals and collectives in the educational sphere) are an integral part of scientific interests in the field of jurisprudence. The article aims at reviewing and analyzing the process of studying legal issues (including participants to educational activities) by Russian and foreign scholars, summarizing the results of their scientific research and drawing the relevant conclusions. Relying on the existing theoretical and practical experience and an extensive set of different research methods (general scientific and specific legal methods), the authors have
\end{abstract}

\footnotetext{
${ }^{1}$ North Caucasus Federal University, Stavropol, Russia.

${ }^{2}$ North Caucasus Federal University, Stavropol, Russia.

${ }^{3}$ North Caucasus Federal University, Stavropol, Russia.

${ }^{4}$ South Ossetian state University named after A.A. Tibilov. Ossétia do Norte, Alânia, Russia.
} 
achieved certain results and reached several conclusions. Their main achievement is new data on various aspects of justice.

Keywords: jurisprudence, legal consciousness, educational sphere, participants to educational activities, methodological approach, legal scholar, legal theory, legal practice.

Resumo: $O$ artigo estuda a consciência jurídica dos participantes das atividades educacionais no processo de concretização dos objetivos educacionais e da efetivação de seu direito à educação. Obstáculos próprios desse tipo de pesquisa condicionados por uma base teórica insuficiente para o estudo da consciência jurídica em geral e como categoria que acompanha a realização de objetivos, capacidades e direitos dos participantes às atividades educativas. Na ciência jurídica russa, esses obstáculos são causados pela prevalência de dogmas ideológicos sobre abordagens científicas objetivas (por exemplo, o conceito de que o estado e a lei irão definhar como institutos desnecessários junto com a formação do comunismo), que é enfatizado pelos estudiosos russos interessados com esses problemas. Com o tempo, as dificuldades acima mencionadas foram sendo superadas e hoje as questões associadas à consciência jurídica (em particular, as pessoas e coletivos na esfera educacional) são parte integrante dos interesses científicos no campo da jurisprudência. $\mathrm{O}$ artigo tem como objetivo revisar e analisar o processo de estudo de questões jurídicas (incluindo participantes em atividades educacionais) por acadêmicos russos e estrangeiros, resumindo os resultados de suas pesquisas científicas e tirando as conclusões pertinentes. Baseando-se na experiência teórica e prática existente e num amplo conjunto de diferentes métodos de investigação (métodos científicos gerais e métodos jurídicos específicos), os autores alcançaram certos resultados e chegaram a várias conclusões. Sua principal conquista são os novos dados sobre vários aspectos da justiça.

Palavras-chave: jurisprudência, consciência jurídica, esfera educacional, participantes de atividades educacionais, abordagem metodológica, acadêmico do direito, teoria jurídica, prática jurídica.

Resumen: El artículo estudia la conciencia jurídica de los participantes de las actividades educativas en el proceso de consecución de los objetivos educativos y realización de su derecho a la educación. Obstáculos propios de este tipo de investigación condicionados por una base teórica insuficiente para el estudio de la conciencia jurídica en general y como categoría acompañante de la realización de fines, capacidades y derechos de los participantes en las actividades educativas. En la ciencia jurídica rusa, estos obstáculos son causados por la prevalencia de dogmas ideológicos sobre enfoques científicos objetivos (por ejemplo, el concepto de que el estado y la ley desaparecerán como institutos innecesarios junto con la formación del comunismo), que es enfatizado por los académicos rusos interesados. con estos problemas. Con el tiempo, las dificultades mencionadas se han superado y hoy en día las cuestiones asociadas a la conciencia jurídica (en particular, las personas y los colectivos en el ámbito educativo) forman parte integrante de los intereses científicos en el campo de la jurisprudencia. El artículo tiene como objetivo revisar y analizar el proceso de estudio de cuestiones legales (incluidos los participantes en actividades educativas) por parte de académicos rusos y extranjeros, resumiendo los resultados de su investigación científica y extrayendo las conclusiones relevantes. Basándose en la experiencia teórica y práctica existente y en un amplio conjunto de diferentes métodos de investigación (métodos científicos generales y legales específicos), los autores han logrado ciertos resultados y han llegado a varias conclusiones. Su principal logro son los nuevos datos sobre diversos aspectos de la justicia. 
Palabras clave: jurisprudencia, conciencia jurídica, ámbito educativo, participantes de actividades educativas, enfoque metodológico, jurista, teoría jurídica, práctica jurídica.

\section{INTRODUCTION}

An intense interest to legal consciousness (including in the field of the educational process) is conditioned by a wide range of scientific, theoretical and practical factors. Theoretical tasks of the Russian legal science are caused by drastic social reforms and conceptual changes in the field of law that aim at transforming the role of the latter in a renewed society. Such changes also affect the corresponding practical sphere, in which state and law strive to form the necessary legal consciousness of citizens to exercise their legal rights, including the right to education. Welldeveloped legal consciousness plays a crucial role in informing citizens of such a right and ability to apply it at different stages. This factor should also promote the achievement of practical goals to improve the legal consciousness of citizens and its role in the implementation of educational objectives. The above-mentioned issues were studied by many scholars of the past. Further in the article, we will emphasize that legal consciousness is the research object of legal and other sciences. However, its role in the realization of educational objectives both in the field of educational motivation and in the implementation of the right to education has not been sufficiently studied.

The above-mentioned objective and provisions necessitate the solution of the following tasks:

1) To determine both objective and subjective factors that influence public and individual legal consciousness in general and in relation to modern Russian society (with due regard to its specifics);

2) To analyze the essence of legal consciousness to further improve it as a practical category and an object of scientific research;

3) To study public and personal legal consciousness as a criterion for determining the legal culture of society and individuals, the development of law in society, the state and characteristics of state legal systems, the level of legality and law and order;

4) To consider the phenomenon of legal nihilism in general and in relation to the Russian society, to identify its causes (common and special), to find ways to overcome it;

5) To define the role of legal consciousness in the process of forming the attitude of individuals and collectives to the educational process, to understand the need for education;

To generalize and systematize scientific research results of not only jurisprudence but also sociology, political studies, philosophy, cultural studies and the humanities. 


\section{METHODS}

Throughout the article, we proceeded from the fact that there is a large number of studies concerned with legal issues. We paid much attention to this concept and the way legal consciousness affects the understanding of educational values. To fulfill the above-mentioned research tasks, we need to work with a universal definition containing the results of previous studies and presenting modern views in the retrospective aspect. We selected the following definition: "legal consciousness is the spiritual integrity of legal and general social ideas, views, perceptions, beliefs, feelings, emotions, states of mind, etc. that ideologically and psychologically defines and perceives legal phenomena" (Bainiyazov, 2006; Vizirenko, 2015).

We analyzed the evolution of scientific ideas on legal consciousness as a factor making individuals and collectives obtain knowledge in the form of an academic degree and realize their right to education. In this case, legal consciousness is considered as a guarantee of citizens being aware of their rights and freedoms (including the right to education) and understanding the possibility of their implementation.

Next, we will demonstrate how legal consciousness helps an individual realize the real (actual) need to constantly improve their educational level (as a guarantee of realizing life goals and professional strives) and get information about actual (in the form of appropriate conditions) and legal (in the form of legislative rights) opportunities for realizing their desire to improve the level and quality of education.

Finally, we will conduct a comparative analysis of the Russian and foreign approaches to legal consciousness in general and as a factor ensuring that an individual (a person and citizen) knows about a whole range of rights and freedoms (including the right to education), as well as means and methods to enjoy the aforementioned legal benefits.

\section{RESULTS}

In the course of the study, we need to consider the main aspects of public and individual legal consciousness (including its role in the understanding of the right to education and the need to obtain it by an individual and society). Let us determine the main problems that arise in the process of forming collective and individual legal consciousness and affect the individual's (person's or citizen's) understanding of: 1) a legal right to obtain an academic degree (in its various forms, having different components and objectives); 2) the actual possibility of realizing the right to education supplemented by a legal necessity (for example, a constitutional obligation in the Russian Federation); 3) the relationship between education and the realization of life goals, professional training and social status. To attain this end, we should refer to various studies on legal consciousness (in the field of the educational process and education).

3.1 The first stage (studying the common issues of legal consciousness) 
The issues of legal consciousness have been comprehensively studied by legal science. In this regard, some scholars even propose to divide this process into separate stages. However, modern experts do not have a common opinion about this matter. Some of them suggest distinguishing three stages of studying legal consciousness: the first - before the Mongol-Tatar invasion; the second - until 1917; the third - after 1918. The criteria for distinguishing the above-mentioned stages are based on the fluctuations caused by the struggle between state and individuals (Migushchenko, 2006). Other scholars insist there are four stages in the study of legal consciousness: the first - from 1917 until the mid-1930s; the second - from the mid-1930s until the mid-1950s; the third - from the mid-1950s until the end of the 1970s; the fourth - from the early 1980s (Yurashevich, 2004). The third group of scholars believes that the study of legal issues in Russia began only in the $19^{\text {th }}$ century. Their position is based on two independent arguments: 1) a full-fledged study of legal consciousness in Russia could begin only due to the codification of the Russian legislation that influenced the study of legal consciousness and stirred an active discussion about the interaction of laws and legal consciousness; 2 ) more or less comprehensive definitions of legal consciousness were introduced into the Russian legal science between the end of the $19^{\text {th }}$ century and the beginning of the $20^{\text {th }}$ century (Leshchenko, 2015).

According to some experts, the Russian legislation was codified in the second half of the $19^{\text {th }}$ century and there was an active discussion about the interconnection of laws and legal consciousness. This period can be considered the starting point for studying legal issues in Russian legal science (Leshchenko, 2015). The codification was both the cause and the consequence of the scientific activity aimed at studying legal issues. The comprehensive study of legal consciousness in the indicated period resulted in the development of its definitions. By the end of the $19^{\text {th }}$ century and the beginning of the $20^{\text {th }}$ century, there had been at least three different definitions of this phenomenon. Legal consciousness is: 1) a positive attitude to law; 2) the totality of legal experiences; 3 ) stable legal views that do not include the psychological component (Korotkova, 2010). While considering the evolution of scientific views on legal consciousness at the turn of the $19^{\text {th }}$ and $20^{\text {th }}$ centuries, scholars noted that even then it was possible to trace a certain relationship between the category of "legal consciousness" and categories of "education" and "enlightenment" based on the corresponding scientific approaches to legal consciousness. During this period, legal consciousness was mainly considered in its interrelation with national culture (Leshchenko, 2015) and is known to be closely connected with education and enlightenment (these two categories are part of any national culture, and culture acts as a research object in the educational process). This approach to legal consciousness was also expressed in the position of pre-revolutionary scholars who associated this phenomenon not only and not so much with law but, to a greater extent, with morality, religion or social goals. Thus, the ideological sphere of legal consciousness is based on national feelings and views (Leshchenko, 2015). In this regard, we can cite the famous Russian prerevolutionary scholar L.I. Petrazhitskii who was the founder of the psychological branch of the Russian legal science. According to his views, law is in closely connected with the human psyche (Petrazhitskii, 1910). The above-mentioned approach provides all the necessary grounds for considering the phenomenon of legal consciousness as a factor making individuals aware of the need to increase their cultural and educational level and the availability of legal, factual and organizational opportunities for this. After all, education is a process of obtaining knowledge, information and is based on intelligence, the human psyche, a system of social and personal views that form an individual and public ideology, which, as mentioned above, pre-revolutionary scholars 
associated with legal consciousness. In connection with the foregoing, there is every reason to believe that this approach laid the foundations for the formation of specific legal consciousness that is called legal ideology. In addition, some sources gave rise to one more type of legal consciousness, i.e. legal psychology. However, we find these sources not in the Russian but rather foreign legal science. For example, European scholars determined the essence of legal consciousness through the prism of feelings and intuition. They denied its reasonable nature. Some German lawyers argued that "legal consciousness or legal conviction is the abstraction of science unknown to people: like the power of love, the power of law is based on feelings; intelligence and understanding cannot compensate the lack of feelings" (Ihering, 1991). The Soviet scholars tried to systematize approaches to a definition of legal consciousness that would combine two components - legal ideology and legal psychology. Thus, the well-known Soviet scholar I.E. Farber distinguished between two aspects in the structure of legal consciousness: 1) the cognitive aspect (legal ideology); 2) the emotional-volitional aspect (legal psychology). Legal ideology is understood as a system of legal ideas that reflect the interests and needs of certain strata. Legal psychology is regarded as a combination of feelings, beliefs, habits and motives of legally significant volitional actions. According to I.E. Farber (1963), legal consciousness is nothing more than a form of public consciousness comprising a set of legal views and feelings, having a regulatory character and consisting of knowledge and assessment of legal phenomena with due regard to justice and new legal requirements that are expressed through various needs (economic and political) and interests of social development. While assessing I.E. Farber's approaches, modern scholars note that he did not consider components of behavior, which indicates the denial of stable behavioral patterns in standard situations (habits, attitudes, values and orientations). However, it is impossible to properly assess the level of legal consciousness, including its individual, public and group aspects, without these components (Leshchenko, 2015). Indeed, this position of I.E. Farber reflected general approaches to legal issues typical of the Soviet period (these approaches were used by all the humanities of this period). Some scholars support general assessments of approaches to legal consciousness in the indicated period as a whole. According to V.V. Safronov (2004), the Russian legal consciousness in the Soviet period did not develop and even suppressed it in every way. V.S. Bredneva claimed that during this period, there was no holistic and clear understanding of legal consciousness and most studies aimed at examining new types of legal consciousness (communist, socialist, revolutionary or class-specific) rather than developing the concept itself. Almost all scholars presented legal consciousness as a class-specific phenomenon determined by social life and living conditions (Bredneva, 2019). Although it is possible to determine common features of the Soviet scientific approaches, the Soviet period as a whole was not uniform in relation to legal consciousness. In the first post-revolutionary years, many Soviet scholars (M.A. Reisner, P.I. Stuchka) highlighted the issues of legal consciousness (Leshchenko, 2015). However, interest in legal consciousness reduced in the period from the mid-1930s until the mid-1950s. Modern legal experts explain this change by difficult political conditions, repressions, Joseph Stalin's cult of personality, the excessive ideologization of the general theory of law and state, the neglect of scientific achievements of that time (Leshchenko, 2015). The changed situation in the country of the mid1950s revived interest in the issues of legal consciousness in various scientific fields (alongside lawyers, sociologists also got involved in such studies). At the same time, Russian science remained squeezed into ideological clutches since the Khrushchev Thaw did not reform the existing system (Lapaeva, 1999). The studies of the above-mentioned period connected legal consciousness with 
the current legislation and law enforcement. There were attempts to draw attention to legal consciousness but science often divided this concept into two meanings, i.e. a category of law and a kind of consciousness (Leshchenko, 2015). One more typical feature of the indicated period was the consideration of legal consciousness as the key component of law and an incentive for the development of other legal concepts. Such views were expressed by O.S. loffe, A.R. Ratinov, M.D. Shargorodskii, etc. (Leshchenko, 2015). In the 1960s, Russian legal science focused on the study of certain types of legal consciousness. Thus, the science of that time mainly considered individual legal consciousness and established its relationship and direct impact on public and group legal consciousness. The Soviet scholars concluded that the constituent elements and unique features of individual legal consciousness form special legal consciousness within one social group (Leshchenko, 2015). In conformity with the specifics of some social and state system, legal consciousness was associated with particular social and state components (legal norms, party programs, public opinion, legal science, human behavior, etc.) (Ostroumov, 1969). Modern scholars question the feasibility of this approach since it makes legal consciousness dependent on political and ideological factors (Leshchenko, 2015). In the 1970-1980s, Russian legal science continued to implement the approaches developed in the previous decades for the study of legal consciousness. This state of affairs could be explained by the fact that legal consciousness was rarely considered an independent category. This phenomenon was studied in close interconnection with other social (in particular, legal) categories, including moral consciousness, law, legal culture, political consciousness, individual legal consciousness and public consciousness (Leshchenko, 2015). The reforms that began in the Soviet society and state in the second half of the 1980s could not but affect the scientific field, especially the humanities (including, jurisprudence). The existing scientific approaches and priorities started to change. In the field of legal science, this process also influenced legal consciousness and conditioned new aspects of studying this phenomenon. The interpretation of public legal consciousness led to the identification of its special subtype, i.e. the legal consciousness of various social groups. This approach led to the development of an independent scientific category (concept) or a model of the social structure of legal consciousness. This model was considered at three levels: public, group and individual (Korotkova, 2010). During this period, the study of legal consciousness ceased to be a monopoly of only legal science. Other sciences (for example, sociology) also joined this process. This science contributed to the study of legal consciousness through the prism of other legal phenomena, including public opinion on law, the prestige of law, the social functioning of law, the legal activity of an individual, etc. The post-Soviet period removed all obstacles for studying legal consciousness, i.e. ideological beliefs disappeared and the corresponding foreign studies became more accessible (Leshchenko, 2015). However, we cannot state that the post-Soviet legal science had completely discarded the Soviet scientific achievements in the field of legal consciousness. On the contrary, it took into account the Soviet experience and supplemented it with the latest results to combine past and modern achievements and create a more complete and diverse scientific worldview. From the theoretical and practical perspective, this approach formed the following views on the concept and category of legal consciousness: 1) legal consciousness reflects legal reality in the form of legal knowledge and subjective attitudes to law and law enforcement, including sociolegal attitudes and values that regulate human behavior in legally significant situations; 2 ) legal consciousness cannot exist apart from other forms of public consciousness (for example, morality or political consciousness) that influence the formation of legal ideas and beliefs; 3 ) the main functions of legal consciousness are informative, cognitive, evaluative and regulatory; 4) the 
informative and cognitive function of legal consciousness promotes the dissemination of legal information and the accumulation of legal knowledge by both individuals and society as a whole; 5) the evaluative function of well-developed legal consciousness enables to evaluate legal phenomena and the regulatory function contributes to the development and dissemination of legitimate behavior.

Today, Russian legal science places the greatest emphasis on the substantive components of legal consciousness, including the structure of legal consciousness, its types, formation methods and factors that determine the deformation of legal consciousness (Pevtsova, 2004). In addition, modern scholars define methods and techniques to study various types and levels of legal consciousness. It is the assessment of legal views, theories, ideas and beliefs in relation to the existing or required legal norms. Today, the Russian legal scholars highlight that legal consciousness comprises different social components: psychological, legal, social, political and moral. Finally, legal consciousness is among those factors that help an individual or society find the right way (to make the right decision) in situations related to the legal sphere (Leshchenko, 2015).

While considering the Russian approach to the study of legal issues, we should also mention the scientific contribution to this topic by the neighboring countries (the former Soviet republics). For instance, the Belarusian scholar A.N. Pastushenya examined legal consciousness in both general and specific legal aspects. Within the framework of the first, the scholar concluded that legal consciousness reflects the legal worldview of a person and includes those personality traits that relate to the phenomenon of consciousness, primarily to the cognitive sphere of the personality (knowledge, perceptions, beliefs, expectations, evaluative standards, personal principles and norms, relationships) (Pastushenya, 2012). According to the second aspect, legal consciousness is considered in connection with the criminal nature of an offender. The scholar believed that this concept served as the methodological basis for studying defects of legal consciousness. Based on the understanding of the individual's criminal nature, such defects of public legal consciousness are manifested in various criminal actions available for some members of society and used to satisfy their needs or solve life problems (Pastushenya, 1998).

3.2 The second stage (studying the issues of legal consciousness in connection with the public and individual comprehension of the importance of education and, accordingly, the legal support of this process, in particular, the consolidation and realization of the right to education, awareness of this right and the possibilities arising from it, participants in the educational process)

Full-fledged legal consciousness helps to realize the need for education, become interested in obtaining an academic degree, understand the need to solve this task and be aware of legal possibilities (the right to education). Undoubtedly, the right to education is conditioned by the high level of legal consciousness of those people who initiated this right and its legislative consolidation in regulatory documents of various nature and level (the Universal Declaration of Human Rights, the Convention against Discrimination in Education, the International Covenant on Economic, Social and Cultural Rights, the Convention on the Rights of the Child, the European Convention for the Protection of Human Rights and Fundamental Freedoms). Considering these facts, we must admit that the political leaders of the post-revolutionary period had a high level of legal consciousness and realized the need to eliminate illiteracy in Russia and provide all the strata of the Russian population with the right to education. 
The objects and subjects of the educational process recognize the need to obtain education since they are aware of the need to implement other life goals. In this regard, education is not an end in itself but rather a means of realizing these goals. Thus, the subject and object's aspirations coincide. The object of the educational activity (an individual striving to get an academic degree and a group of such individuals in society) seeks to achieve certain life goals and understand that it is impossible without getting an appropriate education. To ensure the normal functioning and development of society, there should be individuals capable of promoting such development and functioning. To attain this end, each individual should have an appropriate educational level (which is a prerequisite for obtaining an appropriate profession or specialty and working in the chosen sphere). The higher the development of society, the greater educational standards are set (and educational requirements are applied) to individual members of society. On the contrary, the higher the development of state, the greater the degree to which it understands the need to create appropriate conditions for members of a given society so that they can obtain education. In some cases, an academic degree of a certain level and type is transformed into a prerequisite. For instance, the Russian state of the Soviet and post-Soviet period enshrined the obligation to receive secondary education in its constitutions (Konstitutsiya (Osnovnoi Zakon) Soyuza Sovetskikh Sotsialisticheskikh Respublik, 1936; 1977; Konstitutsiya Rossiiskoi Federatsii, 1993).

An appropriate level of legal consciousness is also necessary for those subjects for which state and society create the relevant conditions for realizing their educational goals, tasks and needs.

While considering the interconnection of such factors as legal consciousness, the right to education and the possibility of its implementation (as well as the need for education and the creation of conditions for its acquisition), we should emphasize the legal consciousness of those subjects who implement educational policies in a particular society. The above-mentioned subjects mainly comprise the state. At the same time, educational policies aim at creating a legislative framework for their implementation. It is also worth mentioning the level and quality of legal consciousness of those subjects that determine educational policies and lay the legislative base in the field of education. Their legal consciousness should help them form conceptual substantive provisions and determine appropriate legal techniques in the process of creating the necessary regulatory framework. Of course, the regulatory framework plays a subordinate role in relation to the tasks posed by state and society in the field of education. This thesis is confirmed by the evolution of the Russian educational policies and, accordingly, laws on education. One cannot but agree with K. Marx and F. Engels who claimed that social being determines public consciousness (Marx, Engels, 1955). Since legal consciousness is a variety of public consciousness, it is also affected by the existing social realities. This naturally applies to the legal consciousness of those state entities that determine any state policy, including educational.

Due to the stratification of the Russian pre-revolutionary society, the ruling elites did not recognize the need to educate representatives of all strata (classes) of the Russian society (Dneprov, 2017). During the Soviet era, public and state consciousness changed, which is both the cause and effect of the new period. People understood that their society should be developed in new conditions (in the conditions of the new socialist system, as stated by the communist leaders). This understanding required a new concept of education and educational policy formed in the minds of the ruling class. The legal consciousness of the Soviet legislator (first of all, state) contributed not 
only to the constitutional consolidation of the right to education, but also to 1) making certain levels and forms of education (firstly, "compulsory eight-year education" (the Constitution of the USSR, 1936), secondly, "compulsory secondary education" (Konstitutsiya (Osnovnoi Zakon) Soyuza Sovetskikh Sotsialisticheskikh Respublik, 1977) constitutional obligations (Konstitutsiya (Osnovnoi Zakon) Soyuza Sovetskikh Sotsialisticheskikh Respublik, 1936; 1977); 2) enshrining the principle of universal education (Konstitutsiya (Osnovnoi Zakon) Soyuza Sovetskikh Sotsialisticheskikh Respublik, 1936; 1977); 3) enshrining the principle of free education of all types (Konstitutsiya (Osnovnoi Zakon) Soyuza Sovetskikh Sotsialisticheskikh Respublik, 1936; 1977).

In the post-Soviet period, legal consciousness was transformed due to several reasons. First of all, we are interested in the legal consciousness of the legislator who adopted laws on education, namely the Constitution of the Russian Federation of 1993. This Basic Law has preserved many provisions (possibly, in its main part) from the Soviet constitutions (accordingly, the Soviet system): 1) compulsory education (designated as secondary in the Soviet constitutions); 2 ) the accessibility and free nature of preschool, primary and secondary vocational education in state or municipal educational institutions and factories; 3 ) the right to obtain free higher education on a competitive basis in a state or municipal educational institution and factory (Konstitutsiya Rossiiskoi Federatsii, 1993). Most likely, this continuity demonstrates that the legislator (and citizens who voted for the draft of the current Constitution) understood the need to preserve positive features of the Soviet educational system in the new conditions. The above-mentioned rights and opportunities also met the interests of the new socio-economic and political system (the competitive environment in all spheres of society required trained people); therefore, the accessibility of education (despite its differences at certain levels) should be preserved.

However, when we read these provisions in the current Constitution of the Russian Federation we can see something "between the lines". Firstly, it is an opportunity to establish alternative state and municipal educational institutions. Secondly, it is a possibility to introduce paid services at the level of vocational secondary, secondary technical and higher education. During the development and adoption of the current Constitution, these "alternatives" did not exist but this document formed a sufficient regulatory framework, allowing these "alternatives" to arise in the future. From a certain time to this day, new social realities and a new state of the post-Soviet legal consciousness have been affecting the approaches of society and each individual to education. As in other cases, two aspects can be distinguished, i.e. formal-legal and real-practical. The first aspect is the constitutional right to obtain education and the fact that state and society make citizens aware of this right and the possibility of its implementation. The second aspect contains real conditions for providing opportunities to receive education at different levels and of different types. Indeed, there are certain pros and cons. We believe the main advantage is alternatives in the educational sphere (this factor is possible due to the legislative principle of multistructural economy). Such alternatives for citizens of the Russian Federation are as follows: the possibility of obtaining education abroad, the possibility of choosing an educational institution of various organizational forms, the possibility of obtaining higher or vocational secondary education on a paid basis if it is impossible to obtain it on a competitive base, the possibility of selecting educational levels (Bachelor's degree or Specialist's degree, Master's degree or refusal of it). The main disadvantage consists in the inequality of real opportunities for 1 ) obtaining individual forms of education (first of all, higher education); 2 ) choosing an educational institution (the division into "elite" and non-prestigious educational 
institutions). There is also a certain imbalance between the list of specialties in Russian higher education and the possibility of real employment. Furthermore, the state of education in constituent entities of the Russian Federation differs in a significant way. The above-mentioned imbalances can be exemplified by the North Caucasian Federal District of the Russian Federation (the Kabardino-Balkarian Republic, the Republic of Ingushetia and Stavropol Krai). The set of problems experienced by these constituent entities over the past few years confirms this state of affairs (Tereshchenko) ${ }^{5}$. A specific indicator of such problems is the fact that citizens appeal to the relevant state organizations, including the commission on human and civil rights, starting from the Human Rights Commissioner in some constituent entity of the Russian Federation and ending with municipal commissioners (Public Children's Commissioners working at the administration of municipal districts and city districts under the Children's Commissioner of the corresponding constituent entity of the Russian Federation). In particular, a certain number of appeals related to the problems that hinder citizens to fully realize their right to education.

This situation in the Russian educational system (as exemplified by constituent entities of the Russian Federation) expressed in a whole set of problems demonstrates gaps in the legal consciousness of the persons responsible for organizing the educational process (who should ensure the realization of the right to education) and proceeds from these gaps. It emphasizes the significant role of legal consciousness (as well as consciousness in general) in creating the necessary environment (having a whole range of measures and conditions) for individuals to obtain the education necessary for themselves and the whole society to realize their own (individual) and public (collective) objectives and tasks.

\subsection{The third stage (considering foreign experience in studying legal consciousness in general} and in connection with the ability of a person and citizen to realize their rights and the possibility of obtaining education)

We should note that foreign jurisprudence and other sciences have accumulated much valuable information on legal issues. This is especially noticeable in countries that have formed rich legal traditions, increased the level of their law and improved the legal consciousness and legal culture of their citizens (Western Europe and the USA).

While studying the issues of legal consciousness, foreign scholars considered this phenomenon from different angles and perspectives. For example, there are studies of legal consciousness that define it as a factor forming lawfulness, i.e. "meanings, sources of power and cultural practices that are considered legal regardless of the persons that use them and purposes of their use" (Ewick, 2006; Silbey, 2005). Some scholars refer to certain aspects of legal consciousness in the context of the related concepts, such as legal culture (for instance, the issues of legal ideology) (Ewick, 2006; Silbey, 2005).

\footnotetext{
5 1) The provision of free textbooks in educational institutions; 2) access to education in special boarding schools for children with disabilities; 3 ) violations of children's rights to get school meals; 4) the study and teaching of native languages in certain republics of the North Caucasian Federal District (the Kabardino-Balkarian Republic); 5) fire safety; 6) the openness and accessibility of information about the activities of educational institutions; 7) corrupted teachers in educational institutions of various types and levels; 8 ) the admission rate in educational institutions of various types and levels; 9) the discrepancy between regulatory documents of educational institutions with the requirements of federal law; 10) the inconsistency of many schools with new requirements for such facilities; 11) the education of children with disabilities; 12) conflicts in school community, etc.
} 
Other foreign scholars examined legal issues from a different perspective. Thus, the U.S. psychologists J. Tapp and F. Levine developed a concept according to which one of the most important factors in the formation of the citizen's legal conscience is their participation in a jury. The authors of this research dwelled on one component of legal consciousness, i.e. the level of legal development. While interviewing potential jurors and those who passed verdicts, the scholars noticed that their participation in court hearings and the adoption of legal decisions changed people's ideas about the meaning, functions of law and the possibilities for its improvement, i.e. increased the level of their legal development (Tapp, Kohlberg, 1971; 1977a; 1977b). More foreign scholars claimed that the jury has significant opportunities to change all aspects of legal consciousness (Chairow, Charrow, 1979; Elwork, Sales, Alfmi, 1982; Greene, Bornstein, 2000; Wegener et al., 2000; Horowitz, 1997; Krauss, Sales, 2001; Berg, Vidmtir, 1975; Bray, Noble, 1978; Gervey et al., 1999; Summers, Kassin, 2001; Cohn, While, 1990; Nier, Mottola, Gaertner, 2000; Zellman, Sears, 1971).

As we have stated above, the issues of legal consciousness are currently considered by representatives of non-legal sciences (for example, sociology). According to some sociological theories, a person is regarded as an actor of modern individualized society. Sociologists also pay much attention to the analysis of moral and legal consciousness (Habermas, 1984; 1985; 1966; Moscovici, 1981; 1993; 1998; Gilligan, 1982; Luhmann, 1995; Luhmann, 1999; Kohlberg, 1958; Kohlberg, 1969; 1976; 1984; Kohlbeck, Levine, Hewer, 1983).

A separate line of foreign research in the field of legal consciousness is to determine the relationship of the individual's legal consciousness and their behavior that can be assessed as lawful or unlawful (Thurstone, 1927). The scientific results obtained by various scholars in the process of studying these issues are as follows: they assume that the person's behavior can be predicted by their intentions based on the cognitive and affective components of social attitudes (Sutton, 2002; Sheeran, Abraham, 2003).

Representatives of psychology (general and social), neurobiology (Turner, 2004) and neuroeconomics (Kahneman, 2003) also contributed to the study of legal issues. The analysis of the corresponding scientific works shows that psychology provides many methods for studying legal consciousness, socialization, the attribution of responsibility and guilt. These methods are an integral part of experiments and correlation studies and represent projective tests, semantic differential, the Thurstone scale, the Likert scale, data collection and interviewing (Brodskii, O'Neal, 1983). While studying legal consciousness in their scientific field, neurobiologists deduced a peculiar pattern of the individual's legal consciousness, namely the dependence between violated legal norms and the pleasure of punishment (i.e. a situation in which one's desire to get the pleasure of punishment is one of the reasons for violating legal norms) (Turner, 2004). At the same time, neurobiologists try to make a formula for lawful behavior (through identifying the reasons that prompt individuals not to violate the rule of law) (Kahneman, 2003; Kenrick, Neuberg, Cialdini, 2004; Greene et al., 2003; 2003; Montague, King-Casas, Cohen, 2006).

A significant impact on the study of legal issues was made by the theory of "Legal socialization of the individual". Studies on the personality's legal socialization began in the late 1960 s in the United States within the framework of legal psychology and soon the "legal socialization" term was introduced into the scientific community (Tapp, Kohlberg, 1971, 1977a; 
1977b; Tapp, 1991). The theory is built over the thesis that effective legal socialization depends on the maturity of legal thinking which is based on cognitive constructs going through three main stages of their evolution (Tapp, Kohlberg, 1977a; 1977b).

An alternative trend in studying legal socialization is the concept of cognitive development. Ellen S. Cohn and Susan O. White contributed to the elaboration of this concept. The main idea is that the theory of social learning (i.e. the law-abiding behavior of a person is determined by social environment) contradicts the main conclusions of the theory of legal development. The scholars noted that the influence of external social environment is secondary in the process of forming legal and values-based beliefs of a person, while their internal psychological state plays a crucial role (Cohn, While, 1990).

In contrast to the first U.S. approaches to the study of legal socialization that focused on subjecting a person to binding norms (when the level of law obedience becomes a criterion of success), the French researcher $\mathrm{Ch}$. Kourilsky-Augeven developed an alternative concept in the late 1980s. According to her beliefs, the criterion of effective socialization is the subject's "knowledge" of progressive components of law and legal culture into which they are "immersed" and whose axiolants are significant to them.

One more important provision of Ch. Kourilsky-Augeven's research was the idea that an individual needs to develop legal environment not only through the formal observance of the letter of law but also through "absorbing" the spirit of law. This informal attitude to law allows the subject to find the right guidelines in the complex conditions of modern society that are characterized by a wide range of social standards and a whole array of legal norms regulating the behavior of individuals in society (Kourilsky-Augeven, 2007).

Within the framework of this article, we consider legal consciousness in conjunction with the attitude of individuals and society to educational issues (the role of legal consciousness in this process) and cannot but say that foreign scholars pay much attention to proper education. Let us highlight those ideas that belong to the sphere of education and show the relation of individuals and society to it through the prism of modern trends. One of these trends is globalization. In this regard, some scholars note that people's views on education become more pragmatic in the era of globalization. For instance, higher education in the context of "global values-based orientations" is no longer a source of fundamental scientific values. "Clients" of higher education mostly appreciate the accessibility and convenience of consuming "goods" or specific knowledge and skills ("consumer satisfaction"), i.e. less efforts to obtain the desired result; economic averaging and efficiency; catchy and functional packages of (CD-ROMs, online covers, etc.) educational programs; the mobile transition/exchange of students/teachers/scholars from different universities/countries; the subsequent maximum commercial feasibility and "convertibility" of acquired/taught knowledge and skills (Stromquist, Monkman, 2000; Gibbons, 1998; Burbules, Torres, 2000). Another trend in modern world that affects people's approaches to education is digital technology. For this reason, foreign scholars note that the importance of digital technologies and the changes they bring to everyday life are more clearly recognized. Information and communication technologies have become one of the incentives for globalization as the formation and development of the world community. Such technologies encourage people to obtain an academic degree (education is stimulated by the need to master these technologies, which affects people's attitude to education) 
and serve as an integral element of education. To receive an academic degree, individuals need to use these innovations (Shapira, 2000). In this context, we should highlight the role of the Internet. Many scholars mention its specific role and significance (including for the educational process and the attitude of individuals and society towards it). In their opinion, the Internet provides an access to a wide range of communication partners, lets users create a group of associates, satisfies almost any search criteria, enables anonymous and "invisible" communication, ensures the maximum psychological and other types of security, does not require any relationships with the interlocutor, allows to realize fantasies about oneself and the world around, train communication abilities, etc. Using the Internet, people can immediately satisfy many of their social needs with the minimum risk of failure, get unlimited access to information that enables self-realization and provides the opportunity to share their achievements and get support (Davis, 1990; Beand, 2002; Campen, 1992).

\section{DISCUSSION}

In the light of the foregoing, there is an urgent need to combine scientific studies from various countries in the field of legal consciousness and its influence on the attitude of individuals and society towards education, the right to education and the formation of educational aspirations. The international legal communication of different peoples and countries is a typical feature of the modern world that has entered the intercultural stage of its development, when the right to diversity in various fields (including education) and its provision become increasingly important. It is all the more necessary to comprehend the state and legal experience of foreign countries because the civilized status of Russia has always been based on the internal balance of Western and Eastern civilizations originated from the Byzantine culture.

The national and international nature of legal consciousness allows combining and adjusting the Russian and foreign sources of law. It conditions difficulties in understanding this phenomenon and multiple views and opinions on legal consciousness.

The importance (as well as the relative universality) of legal consciousness and education as independent research objects (the relationship of these two categories) makes us turn to the corresponding issues considered by non-legal sciences, for example, sociology, psychology, neurobiology and neuroeconomics. Thus, some interpretations (for instance, the legal socialization of an individual) are of much interest for studying the above-mentioned legal phenomena in general and legal culture in particular.

Today, there is a need (and it should be manifested even more clearly in the future) to consider other spheres of society, including the sphere of education, through the prism of legal consciousness. This approach can be exemplified by the realization of the right to education. If we analyze this right in the context of other personal and civil rights, we should refer to the following thesis. On the one hand, the higher the level of legal consciousness of an individual, the better the prerequisites for informing a person and citizen about: 1 ) their rights and freedoms in general; 2) specific categories and types of available (enshrined in different legal documents) rights and freedoms; 3) mechanisms to exercise the existing rights and freedoms; 4) mechanisms to protect the existing rights and freedoms if the need arises. On the other hand, the very existence 
(consolidation) of rights and freedoms, as well as the fact that a person and citizen is aware of them, is a significant prerequisite for forming the corresponding legal consciousness of individuals and society and increasing its level.

The above-mentioned facts apply to the right to education as one of the social rights and are enshrined in legal documents of different types and levels. In addition, well-developed legal consciousness allows an individual not only to be aware of the right to education and ways to realize it but also to recognize the need to obtain an academic degree and increase their educational level. Another question is what is a real incentive for obtaining an academic degree and improving one's educational level: 1) an end in itself; 2) the desire to acquire new knowledge; 3 ) a factor of increasing individual or social prestige; 3) competitive motivation; 4) the key to mastering a certain profession (specialty) and self-realization. Regardless of motivation, society will only benefit from an increase in the number of educated citizens and, to a greater extent, from the quality of their education.

\section{CONCLUSION}

This article considers only certain aspects of legal consciousness and the interaction of this category and the sphere of education (in particular, the relationship among individual's legal consciousness, a legal right to education and the actual possibility of receiving it by an individual who is aware of this right, methods, social and personal educational objectives and orientations). Further study of legal consciousness and its relationship with education and the educational sphere in Russia and foreign countries will increase interest in this issue in the future. Let us summarize the study results and draw the following conclusions:

1) The issues of legal consciousness are the research object of various scholars (not only jurists) both in Russia (during the Soviet period) and in foreign countries; moreover, representatives of each science that turned to the study of legal consciousness focused their attention on such an aspect that corresponded with their scientific field;

2) In the post-Soviet era, more favorable prerequisites appeared for considering scientific achievements of other countries and integrating the results of foreign scientific research into the field of legal consciousness;

3) The issues related to education (the evolution of this category and the corresponding field, the state of education at the global and national levels, the legislative consolidation of the right to education at different levels and the creation of mechanisms for its implementation, problems in the field of education and unequal educational opportunities in various regions and states) are always relevant and question the interconnection, interaction and mutual influence of such categories as "legal consciousness" and "education";

4) We referred to the Russian and foreign studies in the field of public and individual legal consciousness and education. The analysis of the relevant experience enabled to identify close interdependence between legal consciousness and education expressed in various aspects: 1) the level and type of individual legal consciousness significantly affects educational aspirations (one's need to obtain an academic degree, awareness of a legal right to education and mechanisms for its 
implementation, actual ability to exercise the above-mentioned right); 2) the existence of the educational sphere and the legal consolidation of the right to education are essential prerequisites for forming the individual's legal consciousness and increasing its level (through legal education); 3 ) individual and public legal consciousness are closely connected with the category of "education" through the existing public attitudes and requests in this area and secondly appropriate state policies (in this case, state serves as part of society) in the educational sphere (for example, the legal obligation of all citizens to obtain a certain academic degree (often secondary education) in many countries, including Russia);

5) Society, state and individuals should carry out mutual work aimed at the formation of the positive and high-level legal consciousness of a single person and society as a whole (this activity is not only an end in itself or regulator of the legal sphere of society but also a means to optimize the interaction of society and individuals with the educational environment taking into account the perspective of this article);

To improve the educational environment and solve education-related problems, it is necessary to increase the quality and level of legal consciousness of ordinary individuals (the main "consumers" of educational services) and those responsible for solving the above-mentioned problems, including legislators enshrining the relevant legal norms, as well as politicians and public officials ensuring the implementation of these rules, developing educational policies and educational concepts.

\section{ACKNOWLEDGMENTS}

The study was funded by the Russian Foundation for Basic Research and Ministry of Education and Science of North Ossetia-Alania under research project No. 19-511-07005.

\section{REFERENCES}

Bainiyazov, R.S. (2006). Pravosoznanie i pravovoi mentalitet v Rossii [Legal consciousness and legal mindset in Russia]: thesis for a Doctor's Degree in Law Sciences. Saratov: Saratov Law Institute of the Ministry of Internal Affairs of the Russian Federation.

Beand, K. (2002). Internet addiction: Current status and implications for employees. Employment Counseling, 39(1), 2-11.

Berg, K., Vidmtir, N. (1975). Authoritarianism and recall of evidence about criminal behavior. Journal of Research in Personality, 9, 147-157.

Bray, R.M., Noble, A.M. (1978). Authoritarianism and decisions of mock juries; evidence of jury bias and group polarization. Journal of Personality and Social Psychology, 36, 1424-1430.

Bredneva, V.S. (2019). Deformatsiya professionalnogo pravosoznaniya yuristov i tekhnologii ee preodoleniya [Deforming the professional legal consciousness of jurists and ways to overcome it]. Yuzhno-Sakhalinsk: SakhGU. 
Brodskii, S.L., O'Neal, H. (1983). Smitherman. Handbook of scales for research in crime and delinquency. New York: Springer.

Burbules, N.C., Torres, C.A. (2000). Globalization and Education: Critical Perspectives. New York: Routledge.

Campen, A. (1992). The First Information War: The Story of Communications, Computers, and Intelligence Systems in the Persian Gulf War. New York: Afcea IntI Pr.

Chairow, R.P., Charrow, V.R. (1979). Making legal language understandable. Colombia Law Review, 79, 1306-1374.

Cohn, E.S., While, S.O. (1990). Legal socialization: A Study of Norms and Rules. New York: Springer-Verlag.

Davis, J.A. (1990). Attitudes toward free speech in six countries in the mid-1980s: Australia, Austria, Great Britain, Italy, the United States and West Germany. European Sociological Review, 6, 1-14.

Dias, A. F., \& Menezes, C. A. A. (2017). Que inovação pedagógica a pedagogia queer propõe ao currículo escolar?. Revista Tempos E Espaços Em Educação, 10(23), 37-48.

Dneprov, E.D. (2017). Rossiiskoe zakonodatelstvo ob obrazovanii XIX - nachala XX veka [The Russian laws on education of the 19th and early 20th centuries]: collection of documents. Moscow: Higher School of Economics Publishing House.

Elwork, A., Sales, B.D., Alfmi, J.J. (1982). Making jury instructions understandable. Charlottesville: Michie.

Ewick, P. (2006). Consciousness and Ideology. Aldershot: Routledge.

Farber, I.E. (1963). Pravosoznanie kak forma obshchestvennogo soznaniya [Legal consciousness as a form of social consciousness]. Moscow: Yuridicheskaya literatura.

Gervey, B.M., Chin, C.-Y., Hong, Y.-Y., Dweck, C.S. (1999). Differential use of personal information in decisions about guilt versus innocence; the role of implicit theories. Personality and Social Psychology Bulletin, 25, 17-27.

Gibbons, M. (1998). A Commonwealth Perspective on the Globalization of Higher Education. In: P. Scott (ed.) The Globalization of Higher Education (pp. 70-87). Buckingham: The Society for Research into Higher Education \& Open University Press.

Gilligan, C. (1982). In a different voice: psychological theory and women's development. Cambridge: Harvard University Press.

Greene, E., Bornstein, B.H. (2000). Precious little guidance: jury instruction on damage awards. Psychology, Public Policy and Law, 6(3), 743-768.

Greene, J. D. (2003). From Neutral 'is' to Moral 'ought': What are the Moral Implications of Neuroscientific Moral Psychology? Nature Reviews Neuroscience, 4, 846-849. 
Greene, J.D., Sommerville, R.B., Nystrom, L.E., Darley, J.M., Cohen, J.D. (2001). A fMRI investigation of emotional engagement in moral judgment. Science, 293, 2105-2108.

Habermas, J. (1966). Postscript to Between Facts and Norms. In: M. Deflem (ed.) Habermas, modernity and law. London: SAGE.

Habermas, J. (1984). Les aventures de la rasion, Monde.

Habermas, J. (1985). Questions and Counter questions. In: R.J. Bernstein (ed.) Habermas and Modernity. Cambridge: MIT Press.

Horowitz, L.A. (1997). Reasonable doubt instructions: commonsense justice and standard of proof. Psychology, Public Policy and Law, 3, 285-302.

Ihering, R. (1991). Borba za pravo [The struggle for law]. Moscow: Fenix.

Kahneman, D.A. (2003). Perspective on judgment and choice: mapping bounded rationality. American Psychologist, 58(9), 697-720.

Kenrick, D.T., Neuberg, S.L., Cialdini, R.B. (2004). Social Psychology: Unraveling the Mystery. Boston: Allyn \& Bacon.

Kohlbeck, L., Levine, C., Hewer, A. (1983). Moral Stages. Basel: Karger.

Kohlberg, L. (1958). The development of modes of moral thinking and choice in the years 10 to 16. Unpublished doctoral dissertation. Chicago: University of Chicago.

Kohlberg, L. (1969). Stage and Sequence: The Cognitive-Developmental Approach to Socialization. In: D. Goslin (ed.) Handbook of Socialization Theory and Research (pp. 347-480). Chicago: Rand McNally.

Kohlberg, L. (1976). Moral stages and moralization: The cognitive-developmental approach. In: T. Lickona (ed.) Moral Development and Behavior: Theory, Research and Social Issues (pp. 3153). New York: Holt, Rienhart, and Winston.

Kohlberg, L. (1984). Essays on moral development. San Francisco: Harper \& Row.

Konstitutsiya (Osnovnoi Zakon) Soyuza Sovetskikh Sotsialisticheskikh Respublik [The Constitution (Basic Law) of the Union of Soviet Socialist Republics]. (1936). Moscow, USSR.

Konstitutsiya (Osnovnoi Zakon) Soyuza Sovetskikh Sotsialisticheskikh Respublik [The Constitution (Basic Law) of the Union of Soviet Socialist Republics]. (1977). Moscow, USSR.

Konstitutsiya Rossiiskoi Federatsii [The Constitution of the Russian Federation]. (1993). Moscow, Russia.

Korotkova, O.I. (2010). Teoretiko-pravovoi analiz pravosoznaniya kak neobkhodimyi komponent provedeniya politiko-pravovykh reform [The theoretical and legal analysis of legal consciousness as the necessary component of political and legal reforms]. Gosudarstvennaya vlast i mestnoe samo-upravlenie, 11, 5-10.

Kourilsky-Augeven, C. (2007). Legal Socialization: From Compliance to Familiarization through Permeation. European Journal of Legal Studies, 1, 265-295. 
Kovacs, H., \& Tinoca, L. (2017). Unfreeze the pedagogies: introduction of a new innovative measure in Portugal. Revista Tempos E Espaços Em Educação, 10(23), 73-86.

Krauss, D.A., Sales, B.D. (2001). The effects of clinical and scientific expert testimony on juror decision making in capital sentencing. Psychology, Public Policy and Law, 7, 267-310.

Lapaeva, V.V. (1999). Sotsiologiya prava kak yuridicheskaya distsiplina? [The sociology of law as a legal discipline]. Sotsiologicheskie issledovaniya, 7, 47-57.

Leshchenko, O.V. (2015). Teoretiko-pravovye podkhody $k$ ponimaniyu sushchnosti pravovogo soznaniya [Theoretical and legal approaches to understanding the essence of legal consciousness]. Vestnik KGU im. N.A. Nekrasova, 21(3), 174-178.

Luhmann, N. (1995). Das Rechtder Gesellschaft. Frankfurt a. M.: Suhrkamp.

Luhmann, N. (1999). Ausdifferenzierungdes Rechts Beiträgezur Rechtssoziologie und Rechtstheorie. Frankfurt a. M.: Suhrkamp.

Marx, K., Engels, F. (1955). Nemetskaya ideologiya [The German ideology]. Moscow: Gospolitizdat.

Migushchenko, O.N. (2006). Istoricheskoe i logicheskoe v ponimanii pravosoznaniya [The historical and logical components of understanding legal consciousness]. Istoriya gosudarstva $i$ prava, 9, pp. 24-26.

Montague, P.R., King-Casas, B., Cohen, J.D. (2006). Imaging Valuation Models in Human Choice. Annual Review of Neuroscience, 29, 417-448.

Moscovici, S. (1981). On social representations. Perspectives on everyday understanding. In: J. Forgas (ed.) Social Cognition (pp. 181-209). London: Academic Press.

Moscovici, S. (1993). Introductory Address. Papers on social representations, 2(3), 160-170.

Moscovici, S. (1998). The history and actuality of social representations. In: U. Flick (ed.) The psychology of the social. Cambridge: Cambridge University Press.

Nier, J.A., Mottola, G.R., Gaertner, S.L. (2000). O.J. Simpson's criminal verdict as a racially symbolic event: a longitudinal analysis of racial altitude change. Personality and Social Psychology Bulletin, 26, 507-516.

Ostroumov, G.S. (1969). Pravovoe osoznanie deistvitelnosti [The legal consciousness of reality]. Moscow: Nauka.

Pastushenya, A.N. (1998). Kriminogennaya sushchnost lichnosti prestupnika: metodologiya po-znaniya i psikhologicheskaya kontseptsiya [The criminogenic nature of a criminal: cognitive methods and psychological concepts]. Minsk: Academy of the Ministry of Internal Affairs of the Republic of Belarus.

Pastushenya, A.N. (2012). Psikhologicheskaya kharakteristika individualnogo i obshchestvennogo pravosoznaniya: strukturno-soderzhatelnyi aspekt [Psychological characteristics of individual and common legal consciousness: structural and substantial aspects]. Psikhologiya $i$ pravo, 1, 132-142. 
Petrazhitskii, L.I. (1910). Teoriya prava i gosudarstva v svyazi s teoriei nravstvennosti [The theory of law and state in connection with the theory of morality]. Saint Petersburg: Tipografiya M. Merkusheva.

Pevtsova, E.A. (2004). Novaya teoriya pravosoznaniya kak osnova effektivnogo primeneniya prava i preobrazovaniya pravovoi kultury Rossii [A new theory of legal consciousness as the basis of effective law enforcement and transformation of the Russian legal culture]. The proceedings of the 2nd International congress of legal scholars "The innovative development of legal environment", April 25-26. Moscow, Russia.

Safronov, V.V. (2004). Pravosoznanie grazhdanina [The legal consciousness of citizens]: thesis for a Doctor's Degree in Law Sciences. Krasnoyarsk: Krasnoyarsk State University.

Shapira, N. (2000). Psychiatric features of individuals with problematic Internet use. Journal of Affective Disorders, 57, 267-272.

Sousa, J. M. (2016). Repensar o Currículo como Emancipador. Revista Tempos E Espaços Em Educação, 9(18), 111-120.

Sheeran, P., Abraham, C. (2003). Mediator of Moderators: Temporal Stability of Intention and the Intention-Behavior Relation. Personality and Social Psychology Bulletin, 29, 205-215.

Silbey, S.S. (2005). After Legal Consciousness. Annual Review of Law and Social Science, 1, 323-368.

Stromquist, N.P., Monkman, K. (2000). Defining Globalization and Assessing Its Implications on Knowledge and Education. In: N.P. Stromquist, K. Monkman (eds.) Globalization and Education (pp. 3-25). Lanham - New York: Rowman \& Littlefield Publishers, Inc.

Summers, S.R., Kassin, S.M. (2001). On many impacts of inadmissible testimony: selective compliance, need for cognition, and the overcorrection bias. Personality and Social Psychology Bulletin, 27, 1368-1377.

Sutton, S. (2002). Testing attitude-behavior theories using non-experimental data: an examination of some hidden assumptions. European Review of Social Psychology, 13, 293-323.

Tapp, J.L. (1991). The geography of legal socialization: scientific and social markers. Droit et Societe, 19, 329-353.

Tapp, J.L., Kohlberg, L. (1971). Developing senses of law and legal justice, The Journal of Social Issues, 27, 65-92.

Tapp, J.L., Levine, F.J. (1977a). The dialectic of legal socialization in community and school. In: J. L. Tapp, F. J. Levine (eds.) Law, Justice, and the Individual in Society: Psychological and Legal Issues (pp. 163-182). New York: Holt, Rinehart and Winston.

Tapp, J.L., Levine, F.J. (1977b). Law, Justice and the Individual in Society: Psychological and Legal Issues. New York: Holt, Rinehart and Winston.

Thurstone, L.L. (1927). The Method of Paired Comparisons for Social Values. Journal of Abnormal and Social Psychology, 21, 384-400. 
Turner, J. (2004). Human emotions: A sociological theory. London: Taylor \& Francis.

Vizirenko, E.V. (2015). Tendentsii razvitiya pravosoznaniya i pravovoi kultury v sovremennom rossiiskom obshchestve [Trends in developing legal consciousness and legal culture in the modern Russian society]. Mezhdunarodnyi nauchno-issledovatelskii zhurnal, 6-2(37), 89-91.

Wegener, D.T., Fleming, M.A., Kerr, N.L., Petty, R.E. (2000). Flexible correction of juror judgments: implications for jury instructions. Psychology, Public Policy and Law, 6(3), 629-654.

Yurashevich, N.M. (2004). Evolyutsiya ponyatiya pravovogo soznaniya [Evolving the concept of legal consciousness]. Pravovedenie, 2, 165-181.

Zellman, G.L., Sears, D.O. (1971). Childhood origins of tolerance for dissent. Social Issues, 27, 109-136.

\section{$\underline{\text { ABOULT THE AUTHORS }}$}

\section{Elena Anatolyevna Tereshchenko}

PhD in law. North Caucasus Federal University, Stavropol, Russia.

Email: elena-tereshhenk@yandex.ru.

ORCID: https://orcid.org/0000-0003-4422-7488

Vladimir Viktorovich Kovalev

PhD in law. North Caucasus Federal University, Stavropol, Russia.

Email: kraiobetovanny777@mail.ru.

ORCID: https://orcid.org/0000-0003-3327-6751

\section{Maxim Sergeevich Trofimov}

PhD in law. North Caucasus Federal University, Stavropol, Russia.

Email: sim-pai@mail.ru.

RCID: https://orcid.org/0000-0001-8584-6563

\section{Dzambolat Arthurovich Zasseev}

PhD in law. South Ossetian state University named after A.A. Tibilov. Ossétia do Norte, Alânia, Russia.

Email:zasseev.d.a@mail.ru.

ORCID: https://orcid.org/0000-0001-7431-6911 